\title{
Diacronie
}

Studi di Storia Contemporanea

$N^{\circ} 8,4 \mid 2011$

Le sembianze di Clio: approcci alla storia

\section{Globalization and the "Democratic Peace" as Civilizing Forces? The case study of Israel}

\section{Lorenzo Kamel}

\section{(2) OpenEdition}

\section{Journals}

\section{Electronic version}

URL: http://journals.openedition.org/diacronie/3550

DOI: 10.4000/diacronie.3550

ISSN: 2038-0925

\section{Publisher}

Association culturelle Diacronie

\section{Electronic reference}

Lorenzo Kamel, "Globalization and the "Democratic Peace" as Civilizing Forces? The case study of Israel », Diacronie [Online], № 8, 4 | 2011, document 6, Online since 29 October 2011, connection on 02 May 2019. URL : http://journals.openedition.org/diacronie/3550 ; DOI : 10.4000/diacronie.3550 


\title{
Diacronie
}

6/

\section{Globalization and the "Democratic Peace" as Civilizing Forces? The case study of Israel}

\author{
Lorenzo KAMEL *
}

Cosmopolitans, striving to make all human beings part of one worldwide community, are inspired by two developments of today's world: globalization and the so-called "democratic peace". But is this hope justified - do these phenomenons exert a civilizing force? By discussing the case of Israel, i.e. a partially developed democracy, it is found that it is difficult for globalization to become a cosmopolitan force under the circumstances of conflict. Furthermore, democracies are able to project their internal values onto foreign policy only when dealing with other democracies; they display autocratic foreign policy behaviour when dealing with non-liberal states. In this respect a full-fledged and internationally recognized Palestinian democratic state could increase the chances for a future of mutual respect in the Holy Land.

\section{Introduction}

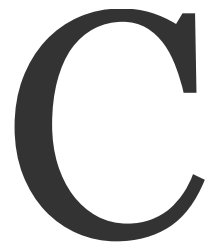
osmopolitanism derives from the Greek word kosmopolitês, which means "citizen of the world". The idea behind cosmopolitanism is that all human beings are part of one worldwide community. Cosmopolitanism went through many waves and received one of its most important inputs during the period of enlightenment. One might accredit Immanuel Kant's Perpetual Peace ${ }^{1}$ as one of the most important piece of cosmopolitan thinking in this time, since it envisions a world-wide peace between republics.

\footnotetext{
${ }^{1}$ KANT, Immanuel, Perpetual Peace: a Philosophical Essay, London, G. Allen \& Unwin Ltd., 1795 .
} 
Other cosmopolitan dreams emerged from economic theory. In The Wealth of Nations $^{2}$, Adam Smith defended the idea that everyone would benefit from the abolishment of protectionism, making everyone better off and minimizing the role of national governments. In a world-wide free trade area, war would be in no one's interest anymore. However, this capitalist cosmopolitanism was harshly criticized by Marx and Engels, who came up with their own version of cosmopolitanism when they called in the Communist Manifesto ${ }^{3}$ to "Proletarians of all countries, unite!" With the first World War, however, both of these cosmopolitan ideas seemed to have failed: Neither the world-wide extensive trade volume prevented the war, nor did the proletarians unite, but to the contrary rallied around their national flags.

Nonetheless, today two new developments give hope to cosmopolitans: the phenomenons of globalization and of the so-called "democratic peace". In the following, first the phenomenon of globalization and its implications for Israel will be discussed, before the article will turn to the "democratic peace" and the case of Israel.

\section{Globalization}

The term globalization today is used in so many forms and meanings that it is increasingly difficult to pin it down in a definition. It refers to the process of globalizing the economy with rapidly increasingly levels of trade in capital and goods, of worldwide travel of persons, and of communication. It also refers to increasing levels of worldwide governance through international organizations such as the United Nations, the World Trade Organization or the International Monetary Fund and other regimes. At the same time also networks of transnational civil society are growing speedily. In addition, globalization also often refers to a process of cultural globalization, in which consumption of other cultures in the form of restaurants, art, or life style becomes increasingly accessible. These processes also bring up questions related to American Imperialism, when especially in low developing countries globalization is equalized with Americanization and has a negative connotation.

All these interrelated processes of globalization make one wonder if this phenomenon of globalization is indeed a civilizing force and if it creates tolerant cosmopolitan societies or xenophobic nationalist ones. This section will discuss this question in the following with the help of the case study of Israel. Israel is an

\footnotetext{
2 SMITH, Adam, The Wealth of Nations, New York, Knopf, 1776.

3 MARX, Karl, ENGELS, Friedrich, The Communist Manifesto, Oxford, Oxford University Press, 1848.
} 
interesting case to study this question, as - on the one hand - it is a society that is heavily oriented towards Americanization with the United States being its most important partner in security affairs, and as - on the other hand - it is a society in conflict. Therefore, it can be a crucial case to study the question if globalization can indeed make societies more tolerant.

\section{Globalization and the Case of Israel}

"Two souls, alas, are dwelling in my breast; And one is striving to forsake its brother" (Johann Wolfgang von Goethe, Faust I)

One might argue with Sznajder4 that two souls are dwelling in Israel's breast: the "citizen warrior" and the "citizen shopper". Concretely, Sznajder argues that «(m)odern Zionism [...] was in some ways an ironic turn back to the ideals of warrior virtue. And the Americanization of Israel, I want to argue, represents an attempt to find a way back into exile, to the secular-Jewish and softening virtues of modern cosmopolitanism» 5 . However, while Sznajder finds both souls in Israeli society, he is optimistic that through consumption and consumerism different cultural traditions within Israel can be commodified, ultimatively transforming Israeli culture and implying an end to violent conflict.

Americanization, or globalization, or cosmopolitanization [...] means that ethnic identities become plural and commercialized. In today's Israel, being an Israeli can mean that one reads Russian papers, goes to a Russian theater and listens to Russian rock music. But being an Israeli can mean equally that one takes one's Jewish Oriental identity seriously and, paradoxically thanks to the influence of Western multiculturalism, rejects everything Western. And being an Israeli also means that non-Jewish Israelis, Palestinians with an Israeli passport, can claim cultural autonomy for themselves. These a just a few examples that demonstrate how ethnic one relations are becoming more plural through consumer goods-and how people are turning into 'citizen shoppers'6.

4 SZNAJDER, Natan, «Consumerism as a Civilizing Process: Israel and Judaism in the Second Age of Modernity», in International Journal of Politics, Culture and Society, 14, 2/2000, pp. 297-314.

5 Ibidem, p. 299.

${ }^{6}$ Ibidem, p. 308. 
This optimistic outlook, however, must be modified by Frosh's findings that Israeli society developed «complex consumer cultures [...] alongside constant but relatively low-level ethnic and national conflicts»7. Thus the citizen shopper and the citizen warrior do not actually contradict or mutually exclude each other. Also advertising in a consumer culture can rally around the flag: around stereotypical portrays of the self and the other. Frosh finds that consumer culture in Israel increased the personal bubble which Israelis created around their personal lives in separation of the space that relates to Palestinians and the conflict. He claims that advertising actually used and invigorated «for the ends of consumption the very strong oppositions between inside and outside, us and them, that animate the ethnic nationalism of warrior societies ${ }^{8}$.

Thus, if a nation is in conflict, this might make the citizen warrior a too strong reality to be broken through by the more cosmopolitan forces of consumerism. However, at this point we need to remember that this finding should be qualified: Israeli might be a most difficult case scenario for cosmopolitanism gaining ground, as it is a society in conflict. Under different circumstances, consumerism might well constitute a force for cosmopolitanism. It might be able to construct new identities such as the citizen shopper. One needs to remember that also national identities were only constructed with the rise of the modern state system. Identity is not a fixed concept, but in constant flux and a person can also hold different identities at the same time. A more convenient example for cosmopolitanism might be the European citizen of today. Living in peace, Europeans adopted a new identity in addition to their local and national identities: the European identity. This example shows that a national and a cosmopolitan identity do not necessarily exclude each other. However, it also shows that peace seems to constitute an important pre-condition for the transformation of identity or the adoption of new, additional identities.

The study of Israel also supports some other findings regarding the processes of how globalization takes effect in specific domestic contexts. Avraham and Fist show that in Israel, there is a very specific kind of globalization at work: they observe a «reconstruction process that may be termed Amerisraelization, where the local is Israeli while the global is American»9. This selective process of globalization is also referred to by Azaryahu. According to him, Americanization in Israel had to be adapted

\footnotetext{
7 FROSH, Paul. 2005. «Penetrating Markets, Fortifying Fences:Advertising, Consumption and Violent National Conflict, Paper presented to the International Communication Association Conference», New York, 2005, p. 6.

8 Ibidem, p.23.

9 AVRAHAM, Eli, ANAT, First, «I Buy American’: The American Image as Reflected in Israeli Advertising», in The Journal of Communication, 53, 2/2003, pp. 282-299, p. 293.
} 
to local conditions ${ }^{10}$ : Coca Cola, for example, had to be translated into Hebrew letters. Similarly, this also applies to American TV shows. Liebes and Katz ${ }^{11}$ point out that different groups see and interpret TV shows with different eyes. Russian Israelis, for example, were much more critical of the American soap opera Dallas, even perceiving it as a form of cultural imperialism, while other groups mainly saw it with more referential eyes, simply comparing their life to the life of the characters in the show.

All these examples show that the cultural context actually remains robust and is at best transformed. Imported products from abroad are indigenized, as is also found by Miller $^{12}$ and Thompson ${ }^{13}$. Furthermore, this findings are supported by political science research. Acharya ${ }^{14}$ for example points out that values can only be exported if there is an absorbent in the import society; in other words, values need to be integrated into local cultures and have to be adjusted to it. This, however, does not actually deny the possibility of cosmopolitanism. This depends on how cosmopolitanism is seen. Held, for example, claims that cultural cosmopolitanism

\begin{abstract}
is not against cultural diversity. Few, if any, contemporary cosmopolitans hold such views [...]. Rather, cultural cosmopolitanism should be understood as the capacity to mediate between national cultures, communities of fate and alternative styles of life. It encompasses the possibility of dialogue with the traditions and discourses of others with the aim of expanding the horizons of one's own framework of meaning and prejudice ${ }^{15}$.
\end{abstract}

In conclusion, this discussion showed that it is difficult for globalization to become a cosmopolitan force under the circumstances of conflict. However, other examples such as Europe show better signs of hope for cosmopolitanism. Furthermore, the discussion also revealed that cosmopolitanism needs to be indigenized, which does not contradict the very possibility of cosmopolitanism to take hold.

\footnotetext{
10 AZARYAH, Maoz, «McIsrael? On the 'Americanization' of Israel», in Israel Studies, 5, 1/2000, pp. 41-64.

${ }^{11}$ LIEBES, Tamar, KATZ, Elihu, «Interacting with 'Dallas': Cross Cultural Readings of American TV», in Canadian Journal of Communication, 15, 1/1990, pp. 45-66.

${ }^{12}$ MILLER, Daniela, «The young and the restless in Trinidad: a case of thelocal and the global in mass consumption», in SILVERSTONE, Roger, HIRSCH, Eric (eds.), Consuming Technologies: Media and Information in Domestic Spaces, London, Routledge, 1992, pp. 163-182.

13 THOMPSON, John, The Media and Modernity: A Social Theory of the Media, Stanford, Stanford University Press, 1995

14 ACHARYA, Amitav, «How Ideas Spread: Whose Norms Matter? Norm Localization and Institutional Change in Asian Regionalism», in International Organization, 58, 2/2004, pp. 239-275.

${ }^{15}$ HELD, David, «Cosmopolitanism \& Globalization», in Logos, 1, 3/2002, pp. 1-17, p. 12
} 


\title{
4. The "Democratic Peace" Thesis
}

The "Democratic Peace" thesis was first pronounced by Immanuel Kant in his essay Perpetual Peace, written in 1795 about republics. There he outlines that

\begin{abstract}
if the consent of the citizens is required in order to decide that war should be declared [...] nothing is more natural than that they would be very cautious in commencing such a poor game, decreeing for themselves all the calamities of war. Among the latter would be: having to fight, having to pay the costs of war from their own resources, having painfully to repair the devastation war leaves behind, and, to fill up the measure of evils, load themselves with a heavy national debt that would embitter peace itself and that can never be liquidated on account of constant wars in the future ${ }^{16}$.
\end{abstract}

This thesis experienced a revival in the late 1970 s and gained momentum in the academia especially with the fall of the Berlin Wall when democracy became a «Zeitgeist»17 and when the third wave of democratization ${ }^{18}$, which had started in Southern Europe and Latin America, swept over to Asia, Africa, and Eastern Europe and the number of democracies surpassed autocracies and semi-authoritarian states. Amartya Sen has called the rise of democracy «the most important thing that had happened in the twentieth century» ${ }^{19}$ and some even believed that the fall of Communism and the "triumph" of democracy constituted the «end of history» ${ }^{20}$.

In this euphoria, the "democratic peace theory" gained momentum. The theory maintains that democracies do not wage war against each other. One of the "pioneers" was Dean Babst $^{21}$, but the academic discussion started with Michael Doyle's two seminal pieces on the issue ${ }^{22}$. In the $1990 \mathrm{~s}$, the research on the issue cascaded. The explanations for this phenomenon are manifold and still discussed. One can distinguish two central strains: procedural explanations and normative explanations. To start with

${ }^{16}$ KANT, Immanuel,op. cit..First Definite Article.

17 DIAMOND, Larry Jay, The Spirit of Democracy: The Struggle to Build Free Societies Throughout the World, New York, Times Books/Henry Holt and Co., 2008, p. 6.

18 HUNTINGTON, Samuel P., The Third Wave: Democratization in the Late Twentieth Century. Norman: University of Oklahoma Press, 1991.

19 SEN, Amartya Kumar, «Democracy as a Universal Value», in Journal of Democracy, 10, 3/1999, pp. 3-17, p.3.

${ }_{20}$ FUKUYAMA, Francis, «The End of History?» in The National Interest, 16, 1989 pp. 3-18.

${ }^{21}$ BABST, Dean, «A Force for Peace», in Industrial Research, 14, 1972, pp. 55-58.

22 DOYLE, Michael W., «Kant, Liberal Legacies, and Foreign Affairs», in Philosophy and Public Affairs 12, 3/1983 pp. 205-235; DOYLE, Michael W., «Kant, Liberal Legacies, and Foreign Affairs, Part 2.», in Philosophy and Public Affairs, 12, 4/1983, pp. 323-353. 
the first, it is argued that democracies have to focus on public goods in order to win elections and so only enter in wars, which they expect to win ${ }^{23}$. Autocracies, instead, concentrate on private goods of the circles that sustain power. Also, cartels are influential in autocracies, but more contained in democracies, and so democracies are less expansionist ${ }^{24}$. Furthermore, democracies are transparent for other states - the debates in the parliament are public and other states can observe the true intentions of a democracy. Fearon argues that «democracies should be able to signal their intentions to other states more credibly and clearly than authoritarian states can, perhaps ameliorating the security dilemma between democratic states» 25 . With the security dilemma in international relations ${ }^{26}$ alleviated, two peace-loving democracies - in Kydd's words two «sheep in sheep's clothing» ${ }^{27}$ - cannot slid into war against their intentions.

The normative explanations of the democratic peace instead argue that democracies project internal liberal norms also to the external level. They value the rule of law in international relations and are able to regulate their relations better. Constructivist scholars believe that the security dilemma is reduced, as democracies trust each other ${ }^{28}$ and can set up security communities ${ }^{29}$ like the European Union.

Empirically speaking, there are two cases, which can possibly contradict the democratic peace theory: the war, waged by the ancient Athenian democracy against the democracy Syracuse, as well as the wars between Israel and Lebanon. For the Athenian case, it has been forcefully argued that Syracuse was perceived by Athens as a

23 MESQUITA, Bruce Bueno de, MORROW, James D., SIVERSON Randolph M., SMITH, Alastair, "An Institutional Explanation of the Democratic Peace» in The American Political Science Review, 93, 4/1999, pp. 791-807.

24 SNYDER, Jack L., Myths of Empire: Domestic Politics and International Ambition. Ithaca, N.Y: Cornell University Press, 1991.

25 FEARON, James D., «Domestic Political Audiences and the Escalation of International Disputes» in The American Political Science Review, 88, 3/1994, pp. 577-592, p. 577.

${ }_{26}$ The security dilemma stems from the anarchy of the international system, as there is no supranational policing force. Thus, states cannot be sure of the other's intention. The security dilemma was already observed by Thukydides who wrote regarding the Peloponnesian War that the "growth of the power of Athens, and the alarm which this inspired in Lacadaemon, made war inevitable». THUCYDIDES, The Peloponnesian War, London-NewYork, J. M. DentE.P.Dutton, 1910. Book 1, 23 [6].

${ }^{27}$ KYDD, Andrew, «Sheep in Sheep's clothing: Why security seekers do not fight each other» in Security Studies, 7, 1/1997, p. 114.

28 RISSE-KAPPEN, Thomas, «Democratic Peace - Warlike Democracies?: A Social Constructivist Interpretation of the Liberal Argument» in European Journal of International Relations, 4, 1/1995, pp. 491-517.

29 ADLER, Emanuel, «Imagined (Security) Communities: Cognitive Regions In International Relations», Millennium: Journal of International Studies, 26, 2/1997, pp. 249-278. 
highly instable democracy ${ }^{30}$. Also the case of Israel and Lebanon is contested: Israel is often seen as an «ethnic democracy» ${ }^{31}$, and Lebanon as an instable «consociational democracy»32. Furthermore and maybe more importantly, Lebanon has been under Syrian hegemony until the disengagement of Syrian troops from the country as a result of the 2005 "Cedar Revolution". The Lebanese government does not hold the monopoly of power in the south of the country, which currently is a stronghold of Hezbollah. Thus, the wars between Israel and Lebanon can hardly be seen as a war between two democracies.

In the following, the democratic peace theory will be discussed for the case of Israel by debating the issue along the lines of Michael Doyle's33 two seminal articles on it.

\section{Democratic Peace and the Case of Israel}

Michael Doyle starts his discussion by asking the question «What difference do liberal principles and institutions make to the conduct of the foreign affairs of liberal states?»34. He identifies the freedom of the individual, which he defines as the «right to be treated and a duty to treat others as ethical subjects, and not as objects or means only» 35 , as the essential principle of liberalism. Liberal states transfer this very principle also to other liberal states and are able to set up international law as a «guarantee of respect» 36 in their relations. This observance can also be applied to the case of Israel, which enjoys good relations with the US - its closest ally - and with virtually all European democracies, even though the EU is repeatedly calling on Israel

\footnotetext{
$3^{30}$ BACHTELER, Tobias, «Explaining the Democratic Peace: The Evidence from Ancient Greece Reviewed», Journal of Peace Research, 34, 3/1997, pp. 315-323; RUSSETT, Bruce M., ANTHOLIS, William 1993, "The Imperfect Democratic Peace of Ancient Greece» in ID., Grasping the Democratic Peace: Principles for a Post-Cold War World, Princeton, N.J. Princeton University Press, 1993, pp. 43-71.

${ }^{31}$ KIMMERLING, Baruch, «Religion, Nationalism, and Democracy in Israel», Constellations, 6, 3/1999, pp. 339-363; PELED, Yoav, «Ethnic Democracy and the Legal Construction of Citizenship: Arab Citizens of the Jewish State», in American Political Science Review 86(2/1992, pp. 432-443; SMOOHA, Sammy, «The Model of Ethnic Democracy: Israel as a Jewish and Democratic State», in Nations and Nationalism, 8, 4/2002, pp. 475-503.

$3^{2}$ ANDEWEG, Rudy B., "Consociational Democracy» in Annual Review of Political Science 3, 1/2000, pp. 509-536; DEKMEJIAN, Richard H., «Consociational Democracy in Crisis: The Case of Lebanon" in Comparative Politics, 10, 2/1978, pp. 251-265; LIJPHART, Arend, «Consociational Democracy» in World Politics, 21, 2/1969, pp. 207-225.

33 DOYLE, Michael W., «Kant, Liberal Legacies, and Foreign Affairs», cit.; DOYLE, Michael W., «Kant, Liberal Legacies, and Foreign Affairs, Part 2.», cit.

34 DOYLE, Michael W., «Kant, Liberal Legacies, and Foreign Affairs», cit., p. 205.

35 Ibidem, p. 206.

${ }^{36}$ Ibidem, p. 230.
} 
to adhere to international law in its dealing with Palestinians, which leads us to the next point.

Towards non-liberal states democracies behave in the same balance-of-power pattern like autocracies or scale even worse, as their foreign policy is also infused by liberal ideology. Doyle points out that liberal policy with powerful non-liberal states «has often raised conflicts of interest into crusades», while with weak non-liberal states, «liberal policy has succumbed to imperial interventions [...] Its interventions, designed to create liberal societies by promoting the economic development and political stability of nonliberal societies, have frequently failed to achieve their objects. Confusion, drift, costly crusades, spasmodic imperialism are the contrasting record of liberal foreign policy outside the liberal world» 37 . He argues that this foreign policy behavior towards non-liberal states can be explained by the belief of liberal states that autocracies lack legitimacy, because they do not respect the freedom of their own citizens. And even more than this, democracies believe that autocracies are inherently aggressive: «conflicts of interest become interpreted as steps in a campaign of aggression against the liberal state». This is due to the atmosphere of suspicion of liberal states against authoritarian states, as they are seen to be in «permanent state of aggression against their own people» 38 . Also Israel is displaying a high suspicion against all authoritarian states in its neighborhood and even the relations with the autocracies with which it has a peace treaty - Jordan and Egypt - have been characterized by a "cold peace". Moreover, in contrast to the will of the international community, it continues to occupy the Palestinian Territories where it pursues a unilateral settlement policy - due to the settlements and related infrastructures, 40 percent of the West Bank is off-limit for the Palestinian population - and exploits the local natural resources at an unprecedented level. As the Israeli human rights NGO B'Tselem explained in its latest report, «most Israeli water drillings in the West Bank 28 of the 42 drillings - are located in the Jordan Valley. These drillings provide Israel with some 32 million $\mathrm{m}^{3}$ a year, most of which is allocated to the settlements».

Secondly, a discussion of the case of Israel also has to assess the liberal character of the state itself. Generally speaking, Israel is a liberal state - Freedom House gives it the highest political liberties score, but a slightly decreased political liberties score 39 . This is due to the fact that several liberal freedoms in Israel are limited to a certain degree for

37 DOYLE, Michael W., «Kant, Liberal Legacies, and Foreign Affairs, Part 2.», cit., p. 324.

${ }^{38}$ Ibidem, p. 325.

39 FREEDOM HOUSE, «Freedom in the World Comparative and Historical Data», 2010

URL: < http://www.freedomhouse.org/template.cfm?page=439 > [Accessed 18 April 2011]. 
its Arab population. Shultziner ${ }^{40}$ claims that also today the "civil rights of the Arab citizens of Israel are far from equal to that of their Jewish counterparts, even though they are equal de jure». In certain circumstances the Palestinian citizens of the State of Israel do not receive the same social services as the Jewish citizens. If, for example, a person wants a home loan from a bank, one of the first requirements in order to obtain it is that he is able to prove that he has served in the army, which Palestinians are exempted from. in addition, media freedom is sometimes restricted by a military censorship. Furthermore, as Arian et al. ${ }^{41}$ point out, the level of freedom of the press that is prevalent in Israel places it at the end of the list of democratic countries, beside countries in Eastern Europe and South America. For the first time since the Freedom of the Press Index began publication, Israel belongs to the group of "partly free" countries. Israeli political culture represents this objective measure well. Most of the public support freedom of expression, but are not prepared to accept criticism of the State of Israel. During the time of the Intifada, a law was introduced, which curtailed the freedom of the family. In 2003 the Law of Citizenship was passed, according to which Palestinians from the territories, who marry Palestinian citizens of Israel do not receive citizenship. Such practices sharpened with the onset of the second Intifada. In 2003, a Palestinian radical newspaper was forbidden and some Palestinian and Arab journalists working for Western media did not receive press credentials from Israel anymore. In 2005, Israel arrested a BBC journalist who had interviewed an Israeli sentenced for spying. BBC had to apologize to Israel in order to get access again. Another British journalist was deported after having been engaged in the International Solidarity Movement. So, Israel is not an entirely liberal state. Regarding its Arab minority, without mentioning the Palestinians in the Occupied Territories, it is in some respects more similar to a "selective" liberal state.

Here, we can already observe an intense interplay between internal and external policies. The constraints in freedom are deeply connected to the Israeli-Palestinian conflict and so, the atmosphere of suspicion is transported from the international to the domestic level and vice versa. As a democracy in constant conflict, the liberal character of Israel suffers. Doyle also comments on this when he argues that «constant preparation for war can enhance the role of military institutions in a society to the point

40 SHULTZINER, Doron, «Between Basic Norms and Basic Laws», 2009,

URL: < http://www.jewishvirtuallibrary.org/jsource/isdf/text/shultziner.html\#_ftn40 > [Accessed 6 December 2009].

${ }^{41}$ ARIAN, Asher, KNAFELMAN, Anna, PHILIPPOV, Michael, "Auditing Israeli Democracy. Twenty Years of Immigration from the Soviet Union», 2009, p. 107.

URL: < www.idi.org.il/sites/english/PublicationsCAtalog/Documents/Democracy_Index 09.pdf $>$ [Accesed 15 September 2011]. 
that they become the society's rulers. [...] Conversely, an environment of security can provide a political climate for weakening the state by constitutional restraints» ${ }^{42}$. In Israel, the military is playing an important role, which can be seen in the phenomenon that several Israeli prime ministers have been formerly chiefs of staff of the Israeli army.

In conclusion, Doyle's finding that democracies do lead an extraordinarily successful foreign policy towards each other, but behave in the typical balance-of-power policies towards non-liberal states, can also be sustained for the case of Israel. Democracies are able to project their internal values onto foreign policy only when dealing with other democracies; they display autocratic (or even worse) foreign policy behavior when dealing with non-liberal states. This is the reason why a full-fledged and internationally recognized Palestinian democratic state 43 could massively increase the chances for a future of mutual respect in the Holy Land.

42 DOYLE, Michael W., «Kant, Liberal Legacies, and Foreign Affairs», cit., p. 228.

43 Once again the UN appears to the majority of the observers as the most suitable place to address such a crucial issue. Not only because the 1947 partition of Palestine was itself the result of a multilateral (not a bilaterally negotiated) decision made by two-thirds of the 56 states which at the time composed the UN, but also because article 1 of its charter is about maintaining international peace and security, while article 2 is about the right of peoples to selfdetermination. Two cornerstones that have always been valid, in 1947 as well in 2011. 


\section{* The author}

Lorenzo Kamel is PhD Student at Alma Mater Studiorum (University of Bologna); he obtained a M.A. in Social Sciences (in the program Society and Politics in Israel) at the Hebrew University of Jerusalem. Since 2011 he is journalist: his articles were published by «Oriente Moderno», «The Jerusalem Post», «PeaceReporter», «Aspen», «Italia Futura» and others reviews and newspapers. His Academic Areas Research are: Israel and the Palestinian territories; construction of collective identities in the Middle East; Middle Eastern minorities; protestant missionaries in the Holy Land; colonialism and decolonialism in the Mashriq; nationalism, nations and nation-states; British policies in the Holy Land; Anglo-Jewish history.

URL: < http://studistorici.com/progett/autori/\#Kamel >

\section{Per citare questo articolo:}

KAMEL, Lorenzo, "Globalization and the "Democratic Peace" as Civilizing Forces? The case study of Israel», Diacronie. Studi di Storia Contemporanea: Le sembianze di Clio: approcci alla storia, 29/10/2011, URL:<http://www.studistorici.com/2011/10/29/kamel_numero_8/>

Diacronie Studi di Storia Contemporanea $\beta$ www.diacronie.it

Risorsa digitale indipendente a carattere storiografico. Uscita trimestrale. redazione.diacronie@hotmail.it

Comitato di redazione: Marco Abram - Giampaolo Amodei - Jacopo Bassi - Luca Bufarale - Alessandro Cattunar - Alice De Rensis Barbara Galimberti - Deborah Paci - Fausto Pietrancosta - Martina Sanna - Matteo Tomasoni - Luca Zuccolo

Diritti: gli articoli di Diacronie. Studi di Storia Contemporanea sono pubblicati sotto licenza Creative Commons 2.5. Possono essere riprodotti a patto di non modificarne i contenuti e di non usarli per fini commerciali. La citazione di estratti è comunque sempre autorizzata, nei limiti previsti dalla legge. 